\title{
TEACHER ARCHETYPES: PERCEPTIONS OF NURSING STUDENTS
}

\author{
Luiz Anildo Anacleto da Silva ${ }^{1}$, Rafael Marcelo Soder², Sandra Márcia Schimdt', Helena Carolina Noal ${ }^{4}$ Éder \\ Luís Arboit ${ }^{5}$ Vera Regina De Marco
}

${ }^{1}$ Ph.D. in Nursing. Professor, Departamento de Ciências da Saúde, Curso de Enfermagem, Universidade Federal de Santa Maria (UFSM). Palmeira das Missões, Rio Grande do Sul, Brazil. E-mail: luiz.anildo@yahoo.com.br

${ }^{2}$ Ph.D. in Nursing. Professor, Departamento de Ciências da Saúde, Curso de Enfermagem, UFSM. Palmeira das Missões, Rio Grande do Sul, Brazil. E-mail: rafaelsoder@hotmail.com

${ }^{3}$ Ph.D. in Nursing. Hospital Universitário de Santa Maria. Santa Maria, Rio Grande do Sul, Brazil. E-mail: sandramarciasoares@ gmail.com

4'M.Sc. in Nursing. Hospital Universitário de Santa Maria. Santa Maria, Rio Grande do Sul, Brazil. E-mail: helenacnoal@gmail.com

${ }^{5}$ M.Sc. in Nursing. Professor, Curso de Enfermagem, Universidade de Cruz Alta. Cruz Alta, Rio Grande do Sul, Brazil. E-mail: eder. arb@bol.com.br

${ }^{6}$ Nursing undergraduate. Departamento de Ciências da Saúde, Curso de Enfermagem, UFSM. Palmeira das Missões. Rio Grande do Sul, Brazil. E-mail: vera_demarco@hotmail.com

\begin{abstract}
Good interpersonal relationships between teachers and students are primordial in nursing education. The aim of the study was to understand the perception of the students on the teachers' attitudes that contribute to their professional education. A qualitative, descriptive and exploratory research was undertaken. The subjects are nursing students in the final course term of four distinct undergraduate courses, two of them from a public university and two from a private university, totaling 72 students. Based on the data analysis, the results permitted the construction of five empirical categories, namely: knowledge of teachers; teachers' posture; respectability in the teacher-student relationship; ethics in the teacher and student relationship; responsibility in the teaching pratice. It was concluded that, independently of the institution and course, among many teacher attributes, the students particularly value the density of knowledge.
\end{abstract}

DESCRIPTORS Nursing. Education, nursing. Ethics, nursing. Faculty, nursing. Students, nursing.

\section{ARQUÉTIPOS DOCENTES: PERCEPÇÕES DE DISCENTES DE ENFERMAGEM}

RESUMO: Boas relações interpessoais entre docentes e discentes são primordiais na formação em enfermagem. O objetivo do estudo foi conhecer a percepção dos estudantes, quanto às atitudes docentes que contribuem para a sua formação profissional. Trata-se de uma pesquisa qualitativa, delineada como descritiva e exploratória. Os sujeitos do estudo são acadêmicos de enfermagem que estavam cursando a última fase da graduação de quatro cursos distintos, sendo dois cursos de universidade pública e dois cursos de universidade privada, totalizando 72 estudantes. A partir da análise dos dados, os resultados possibilitaram a construção de cinco categorias empíricas, a saber: conhecimento dos docentes; a postura docente; respeitabilidade na relação docente-discente; ética na relação entre docentes e discentes; responsabilidade no exercício da docência. Concluiu-se que os acadêmicos, independentemente de instituição e curso de origem, valorizam, dentre muitos atributos docentes, em especial, a densidade do conhecimento.

DESCRITORES: Enfermagem. Educação em enfermagem. Ética em enfermagem. Docentes em enfermagem. Estudantes de enfermagem.

\section{ARQUETIPOS DOCENTES: LAS PERCEPCIONES DE LOS ESTUDIANTES DE ENFERMERÍA}

RESUMEN: Las buenas relaciones interpersonales entre los docentes y los estudiantes son esenciales en la formación de enfermería. El objetivo del estudio fue entender la percepción de los estudiantes, los profesores actitudes que contribuyan a su formación profesional. Se trata de una investigación cualitativa, descriptiva y exploratoria. Los sujetos del estudio son estudiantes de enfermería que cursaban el último año del pre grado de cuatro cursos diferentes: dos cursos de universidad pública y dos de universidad privada, para un total de 72 estudiantes. Del análisis de los datos, los resultados permitieron la construcción de cinco categorías empíricas, a saber: el conocimiento de los profesores; la actitud del profesor; respetabilidad en la relación profesor-alumno; la ética en la relación entre profesores y estudiantes; responsabilidad en la profesión docente. Se concluye que independientemente de la institución y del curso de origen, los estudiantes valorizan entre muchas aptitudes docentes, especialmente la profundidad del conocimiento.

DESCRIPTORES: Enfermería. Educación de enfermería. Ética de enfermería. Docentes de enfermería. Estudiantes de enfermería. 


\section{INTRODUCTION}

Higher education contributes to the development of subjects and society, through the enhancement of technological innovation, the production and dissemination of science and culture, and particularly to people's education, to the qualification of work and, consequently, to social improvements.

Higher education institutions, particularly health courses, need to insert flexibility, interdisciplinary, contextualization, actions to link theory and practice and the valuation of ethical, esthetic and political premises in their curricular proposals. As for teaching, the intention is to transcend technical education, privileging active, critical-reflexive approaches to enable the students to construct technical, ethical, political and social knowledge.

Teaching is based on a set of knowledge that constitutes a universe of meanings and senses. Teaching work is based on distinguished knowledge, revealed in daily practice, including experience, personal aspects, feelings that are discovered and constructed in the work itself. ${ }^{1}$

The teacher is the professional responsible for education at universities. In this situation, teaching work corresponds to a set of specific actions, such as content development, compliance with objectives, deadlines and targets. The teaching activities also include planning; orientations; community services; advice and consulting; research; knowledge production; participation in committees; among other activities. These functions, depending on the scenario/situations and how they are developed, can influence the teachers' wellbeing. ${ }^{2}$

The teaching-learning process in nursing is largely based on the relation between theory and practice, whether in the academy or in health services. The teaching activity is an important element in the integration of knowledge into nursing as the teachers, based on their experiences, provide the support needed for professional development. It is in the teacher-care relationship that the future professionals will take form. In this context, the teachers do not only instruct, but also motivate the students in decision making and in the development of skills and attitudes aimed at the acquisition of technical, social and political knowledge for the benefit of society. ${ }^{3}$ Therefore, teaching practice is a complex social activity that combines different tasks, knowledge, attitudes, expectations, actions and strategies, according to the teachers worldview. The teaching activity is also influenced by the culture of the institutions and groups, as the teachers themselves continuously encourage and produce knowledge. ${ }^{4}$

Nowadays, the nursing education process represents an important challenge, which is to prepare professionals with technical, theoretical, scientific and political competencies, with knowledge, perception and sensitivity to social issues, resulting in graduates who are able to intervene in contexts of uncertainties and complexities. Nursing education takes place in different spaces, in a range of relationships, moments and subjects, and this interaction is fundamental to prepare distinguished professionals who can live together and reflect on the reality, with critical thinking and aware of their present and future responsibilities. ${ }^{5}$

Considering teaching as an activity that demands theoretical and practical knowledge from the teachers, as well attitudes and experiences that can influence and contribute to nursing education, the following research question was established: what teacher attitudes contribute to nursing education according to the students? In search of these answers, the objective in this study was to discover how the students perceive the teacher attitudes that contribute to their professional education.

\section{METHOD}

A qualitative, ${ }^{6}$ descriptive and exploratory research was undertaken. ${ }^{7}$ The subjects who participated in the study were students in the final semester of the undergraduate nursing course at four different institutions, two from public and two from private universities. Twenty-three students from a nursing course at public university $1 ; 15$ from a nursing course at public university 2; 13 nursing undergraduates from private university 1 ; and, finally, 21 from private university 2 . Therefore, 38 students come from public and 34 from private universities, totaling 72 students. The data were collected in the second semester of 2013. The thematic analysis method was used to assess and interpret the data. ${ }^{8}$

The following inclusion criteria were considered: being regularly enrolled, being a final-year student, without any pending subjects and agreeing to take part in the study. The data were considered saturated per research unit when the objectives per place of data collection were able to respond to the research objective, in addition to the redundancy in the answers. As a research tool, a questionnaire with two questions was used: the first question discussed the teacher attitudes the students found important in nursing education, and the second 
about what teacher attitudes did not contribute to nursing education. In this text, the data related to the first question was discussed.

All ethical aspects were complied with in accordance with Resolution 466/2012. Approval for the study was obtained from the Ethics Committee for Research Involving Human Beings of Universidade Federal de Santa Maria, under Opinion 555.180. To guarantee the subjects' secrecy and anonymity, the subjects are identified using a code that mixes letters and numbers, e.g. in $\mathrm{C} 1$ ' $\mathrm{C}$ ' means course, therefore, $\mathrm{C} 1$ for the public course 1, $\mathrm{C} 2$ for the public course 2, C3 for the first private course and $\mathrm{C} 4$ for the second private course. The interviews are identified using the letter ' $S$ ' for student, following by the respective numbers, according to the order in which the data were collected.

\section{RESULTS AND DISCUSSION}

The research data show that, in order of importance, independently from the course they belonged to, the attitudes the students considered most important were: the teachers' knowledge (33 answers); the teachers' posture (15 answers); respectability in the teacher/student relation (14 answers); responsibility and ethics in teaching practice (11 answers). In course 1 (public), the most valued attitudes in order importance were: knowledge, posture, respect, ethics and responsibility. In course 2 (public), the attitudes were knowledge, respect, responsibility, posture and, finally, ethics. In course 3 (private), the study subjects chosen premises like knowledge, posture and respect. In course 4 (private), knowledge, posture, responsibility, respect and ethics. Knowledge was the attribute the students in all courses valued most, followed by posture and respect.

Based on the data analysis, five empirical categories emerged, which were: teachers' knowledge; teachers' posture; respectability in the teacher-student relationships; ethics in the teacher and student relationship; responsibility in the teaching practice.

\section{Teachers' knowledge}

The theoretical and practical knowledge is fundamental for teaching practice, also including ethical, social and political knowledge. The teachers' action in this respect needs to transcend the condition of knowledge transmitters to a position of mediators in the learning and teaching process. For the study subjects, encouraging the construction of knowledge is fundamental for their education:
[...] knowledge and the way it is transmitted. And, mainly, the strength and stimulus the teacher gives to the student to always seek further professional qualification and scientific initiation and proceed with the academic life (C1-S1).

Despite ratifying the importance of theoretical and practical knowledge, the teachers get involved by encouraging study, reflection, showing routes and, mainly, investing interactively in the relations between teachers and students. Therefore, the respondents consider the importance of possessing particularly:

[...] patience, dedication, knowledge in theory and in practice. Some teachers always wanted to show new ways and encouraged us to pursue the knowledge (C2-S8).

The teacher-student relationship involves a condition of cordiality, using the dialogue as a parameter, mediated by different levels of requirement. It should be highlighted that the requirement between teachers and students is strengthened reciprocally and fed by the relentless search of knowledge. In that sense, interactivity is another attribute the students value:

I believe the teacher demands attitudes from the student and possesses knowledge in his activity area and knows how to demand (C3-S1).

We had classes with different teachers, each with his own personality, but what motivated me most to participate in the classes was the extroverted behavior to explain the subject one teacher used. These include problem solving and discussion among the groups, having knowledge of the content to gain confidence (C4-S6).

The teaching activity is complex because it involves a range of attributes, including knowledge, skills and attitudes, in addition to the teaching experiences. In their practice, the teachers systematically produce knowledge, which is based on educative practice. When used appropriately, the dialogue, analogies and example facilitate the learning process. $^{4}$

From the study subjects' perspective, the density of the teachers' knowledge is considered the main criterion that strengthens the relationship between teachers and students. The teachers' knowledge, however, rests not only on the specificity of the technical area or of specific knowledge, but mainly on correlated areas, which represent an important factor in education and in the construction of knowledge that supports the academic trajectory. Nevertheless, the students' constitution of knowledge is not the teacher's sole responsibility, as the 
students are responsible for engaging in activities that encourage the educative processes.

Teaching work is multiple, as it includes a series of knowledge, such as technical knowledge, professional experience, skills, perception and knowing how to intertwine theory and practice. In pro-active educative action, the teacher serves as an educator, as a learning mediator, mainly concerning the interrelation between theory and practice. The teacher needs to move beyond the transmission of knowledge by encouraging, articulating and facilitating the students' insertion in the educative process, allowing them to move from a passive learning function to an active role in knowledge construction. ${ }^{9}$

The reorientation of nursing education, especially focused on the Unified Health System (SUS), attributes knowledge, skills and attitudes to the teachers that underlie the disciplinary, pedagogical, curricular and personal knowledge that enables them to teach competently. As regards the knowledge, the authors provide a definition of the construct pedagogical knowledge, which is considered as 'baseline knowledge' for effective teaching practice in the approach. In addition, there is the "content knowledge, knowledge of the students, knowledge of the curriculum, general didactical knowledge, didactical content knowledge, knowledge of the educative contexts and knowledge of the objectives". 10:805

The set of knowledge required for competent teaching includes the "academic education, materials and context of the institutionalized educative process, research and study on teaching, human learning and other issues that influence the teaching practice and the empirical experience originating in the teaching practice itself" ..$^{10805-6}$

In the teacher and student relationship, the knowledge construction itself represents a challenge that guides both subjects to think, reflect, conceive and articulate multiple distinguished forms of knowing. The search for knowledge is established in the inquiry, in daily reflection and induces reflection. This attitude allows the individuals to become the subjects of their own history, citizens inserted in different contexts: social, political, economic and cultural and who, consequently, when they integrate the different sources of knowledge, can move beyond to new forms of knowing. Consequently, alternative forms of knowledge construction can emerge, as they share the diversity of knowledge and combine forms of reflexive thinking and acting with accountability. ${ }^{11}$

\section{The teachers' posture}

The teachers' attitudes are fundamental in educative action, especially in the humanization of the relationships, through actions that abate the intolerance, project the collective and construction and development of values and mainly the enhancement of respectability. The study subjects value attributes like ethics, responsibility, respect and particularly the teachers' posture:

I find the example fundamental, as the students try to follow what the teachers reproduce. In addition, the ethical posture that demonstrates accountability for academic education. Besides the claim for an appropriate posture, in line with the needs/requirements of the profession (C1-S12).

The posture towards the students; being offhand and knowledgeable about the content; creative in developing the activities offered inside the classroom (C2-S4).

The inter-relationship between teachers and students is important and lacks articulation with the commitment to and adoption of interactive practices aimed at approximation and comprehensive practice.

I think of the teachers' commitment to the students and the adoption of an appropriate posture in interaction with the students (C2-S3).

Taking a stand towards people, having respect for different opinions and valuing the students' opinion (C4-S16).

Traditional teaching puts the teacher at the heart of the process, as the subject who thinks, makes the decisions, defines the content and forms, while the students' position in the process is excessively passive. The inter-relation between teachers and students in a pro-active, innovative and reflexive process, as opposed to traditional teaching, is committed to the valuation of a more symmetrical and dialogued relationship between teachers and students, as well as to the interaction between the students and formal, political and social knowledge. In this perspective, education is the base for the construction of the political subject, capable of seeing and overcoming conditioning factors and creating future opportunities. ${ }^{12}$

The teachers' action is fundamental not only in the teaching-learning process focused on technical knowledge, but also in ethical education and in the future professionals' posture. Therefore, educative action needs to root in critical and reflexive teaching with a view to strengthening the development of skills and competencies that strengthen professional practice in the future. ${ }^{13}$ 
The success of a teaching-learning strategy rests on the teacher-student integration and on a relationship that adds motivation in the construction of knowledge. Interactivity in educative action permits knowledge exchange, mediated by constant changes and the valuation of roles. ${ }^{13}$

Traditional teaching is based on knowledge transmission. As a result of the quantitative valuation of contents, in which the teacher adopts fixed positions about how to conduct the educative process and plays a disciplining role, the exchanges and interactions with the students are fragile, as the relation is mediated by the content, times and strict discipline. Discipline, attention and concentration are valued in the students as the tripod to gain knowledge. As a counterpart, innovative educative action is intended to constitute a more integrative relationship between teachers and students.

\section{Respectability in the teacher-student relationship}

The teacher-student relationship needs to be constructed based on dialogue and joint action for the sake of the students' enhanced education, with respectability as one of the parameters to be observed.

Mutual respect, the attitudes that rather demonstrate the student's interest instead of the teacher's interest. These attitudes, present in a few teachers, made the difference in my education, and these teachers are my mirrors, which I will always consider as a reference in my personal and professional life (C1-S5).

The teacher should be respectful, knowledgeable, ethical, creative and adopt an appropriate posture (C2-S4).

It is very important for the teacher to be knowledgeable, have faith in what he does, the desire to teach and, mainly, respect for the student (C3-S8).

I think the teacher should be respectful, make efforts, dialogue (C4-S11).

The good relationship between teachers and students is linked to the welcoming, because of the proximity, the dialogue, substantiated in a respectful and productive pedagogical practice to facilitate the learning, that is, the interaction between teachers and students interferes in the learning. Nevertheless, strategies need to be developed to approach teachers and students, with a view to minimizing the elements that weaken the relationship and strengthen the self-esteem. ${ }^{14}$

The interaction between teachers and students is linked to the achievement of the educational objectives, through an attitude of co-accountability for the learning, the development of partnerships and mutual respectability, also permitting further interaction and participation. ${ }^{15}$ In the interaction, it is crucial to invest in educative actions that give the opportunity for debate between teachers and students, based on the analysis of readings and the implementation of participatory methods that allow for approximation between teachers and students. Thus, a panorama develops in which both construct joint knowledge, creating a pro-active circle of motivation for the students. ${ }^{13}$ The students' effective inclusion in the educative process makes them more critical and aware of the need for the education, a fact that allows them to understand and transform their reality. Therefore, the students' inclusion in the educative process permits the ongoing assessment of coherences and contradictions in professional education. ${ }^{16}$

Both teachers and students are responsible for knowledge construction, using different activities, such as reflection, evidences, examples, generalizations and analogies. The teacher and student relationship means that both are in a constant learning process, although at different levels. Hence, this is a dynamic relationship that does not permit passiveness, a situation in which the pioneering nature refers to the relationship, in which the students abdicate from the passiveness and take charge of their knowledge construction. The innovation in the teacher-student relationship for knowledge construction is characterized as follows: the relations are significant, dialogical, interdisciplinary and developed according to the needs of the subjects and society. ${ }^{17}$

Respect should serve as a mediator in the teacher-student relationship. For the students, respect is one of the attitudes that facilitate the relationship. It is inspired and constructed in the daily relationships, in which both subjects use dialogue and daily contact to overcome the limits, solve conflicts and establish jointly constructed bonds. Respect is inherent in interpersonal relationships, independently of the social and/or professional position and, what is more, they are strengthened and based on converging attitudes, in which both subjects use dialogue.

\section{Ethics in the teacher and student relationship}

Ethics in nursing teaching departs from the articulation between educative action and care, as teaching/research community servicers extend to the services. In educative action, humanization, respect, knowing how to listen, welcoming and 
dialoging. In the relationship between teachers and students, the learning goes beyond the technique, as it includes the modes of doing and being, open and true, the non-overlapping and promotion of the subjects. For the study subjects, the ethics in the teacher relationship comes with other attitudes, mainly the teacher's posture:

I believe that attitudes like listening to the students, being ethical, honest, understanding, accepting criticism. And the attitudes opposed to the above were also important, as that is how I learned how I should not behave or what I should not do and they encouraged me to seek new ways of doing, besides becoming more critical and taking a stand in being/doing (C1-S6).

Valuation of the student's positive points/qualities, the teacher's flexibility, compliance with ethics and accountability for teaching, accounting for the content assessment, and also compliance with times and dates (C2-S12).

Taking a stand and adopting ethical behavior (C3-S11).

What matters is for the teacher to encourage the students, to be competent, be credible in what he says, does and be ethical (C3-S4).

The assertion of ethics in nursing teaching is preponderant in professional education. For teaching practice, the ethical knowledge and the normative and deontological spaces need to expand. In educative practice, the use of methods that facilitate the interaction can attribute a new meaning to the education with a view to a professional education, in which the graduates possess theoretical and practical knowledge that enables them for professional practice, but also for the practice of citizenship, politics and ethics. ${ }^{18}$

Teaching ethics is cross-sectional and ongoing in nursing education. Therefore, should all teachers possess the ethical aspects of teaching in their theoretical background, independently of their activity area? Is ethics teaching part of the structuring subjects? Are the teachers committed to the principles of ethics? Does the ethics developed in the academic sphere rest on deontological issues? Do the current and future conflicts between individuals and nature involve situations that afflict the subjects, as well as living conditions related to citizenship and human rights? ${ }^{19}$

Understanding the ethics in teaching is complex and demands continuous practice. The academic approach of ethics needs to move beyond theoretical and prescriptive teaching, needs to become more practical, integrate the ethical premises with daily issues, whether in the academy or in the services, by confronting the theoretical with what is real, permitting important reflections on thinking and practicing. The reflection on ethics in teaching is linked to its educative role. Nevertheless, stable intervening factors need to be taken into account, such as the pedagogical project, the link between theory and practice, the educative objectives and the training and practicum areas.

Involved and entangled in this context, the practice of ethics in the training and practicum areas, mainly concerning the relation with the users, family and multidisciplinary team, makes the ethical issues flourish and need to be discussed to support nursing education. In that sense, the teacher faces the main challenge, which is to collectively reflect with the students and mediate these dilemmas.

\section{Responsibility in the teaching practice}

In the relationship between teachers and students, the teacher is responsible for the pedagogical development; therefore, the strengths and weaknesses need to be considered in the pedagogical practices. Responsibility is considered an important factor among the teacher attitudes that contribute to the education of future nursing professionals:

The responsibility as a teacher to transmit the content in the classroom ethically, coherently and clearly. The demonstration that nursing was a course the teacher would like to have taken and transmit that to the students, the love of the profession (C2-S10).

The teacher should be competent, master the content and take a stand, should be accountable for the professional experiences (C3-S5).

First, be accountable, committed, be organized, be knowledgeable (C4-S14).

The responsibility for the teacher's role in the knowledge construction permeates the different spaces, moments and scenarios. In this context, the respect between the teachers and students constitutes one of the bases of academic education. In the theoretical-practical activities and supervised training scenarios the students have contact in, the 'practice', including the accountability of the stakeholders, whether these are workers, teachers, students and mainly users and family members, is densely pedagogical. ${ }^{20}$

The responsibilities in the teacher-student relationship are equivalent and equitable, in which both need to take on their respective roles in the educative process, as it is in contiguous work that the professional and the citizen prepared to cope 
with the complexity of social needs are pedagogically constructed.

\section{CONCLUSIONS}

The teaching profession is multiple and complex, involving teaching, research, community services, management, advice and consulting, among other activities. Although all of these are important, teaching is the essence of the profession. Knowing/ understanding the relations established between teachers and students more properly, on the other hand, is an important factor to achieve the educational objectives.

The research subjects consider that some determining factors/attitudes of the teachers are fundamental in their education, including knowledge, posture, respect, ethics and responsibility. Overall, the subjects' answers reveal that the students consider the teacher's knowledge as the most important requisite for their education.

The knowledge the student requires is not only theoretical and practical, but also includes attitudes like relationships, empathy, constant encouragement of discussions with a view to reflecting between what one learns in the theoretical bases and what one does in practice and training.

For the research subjects, the teachers' posture is directly related with the mode of thinking and acting in the academic universe. Associating other requisites like ethics and accountability, they establish the interfaces between students and teachers and with the multiprofessional team, users and family members. In this context, the teachers' pro-active posture among the different stakeholders in academic education permits approximation, bonding and integration between knowledge and action, mainly in the practical contexts.

Respectability is inherent in human relationships. Mutual respect between teachers and students is fundamental for the construction of stable relationships, the development of mutual trust and attitudes that value the students' heterogeneity as, although they are part of a group, their individual peculiarities need to be taken into account.

The students consider the teachers' demanding attitudes towards learning fundamental, such as the stimulus to go beyond and fully insert them in the processes that permeate the education. Although the subjects' answers can arouse countless reflections, in some answers, the students consider that many teachers serve as a 'mirror' that will reflect in different dimensions of their future.
The practice of ethics, together with respectability and accountability, is appointed as a preponderant factor in the teachers and students' relations. In this way of becoming, ethics does not possess reductionist connotations, but is marked by thought, by attempting to move beyond the daily in order to understand, in nursing education, how ethics overarches/crosses the issues inherent in nursing practice. Accountability is related to the teachers' attitude of effectively assuming their responsibilities, to the interest in truly working and engaging the students individually and as a group, besides developing actions based on good contact, respect and empathy towards the students.

Despite structural and organizational distinctions and differences in access to higher education between the public and private universities in terms of teaching, research and community services, the undergraduate nursing students' main objective is teaching. In this aspect, the teachers' attitudes the students highlighted are similar, showing knowledge as the most important factor in all courses, followed by posture, respect, responsibility and ethics.

Finally, in view of the study limitations, as the research findings arouse new questions, it should be highlighted that the intent was to disclose what teachers' attitudes the students consider important for their education. This research does not aim to establish relations, parameters and provide guidance, but basically to arouse reflections on the relationships between teachers and students in the academic sphere, and thus particularly contribute to nursing education.

\section{REFERENCES}

1. Oliveira GS, Koifman L. Uma reflexão sobre os múltiplos sentidos da docência em saúde. Interface [internet]. 2013 [cited 2014 Oct 23]; 17(44):211-8. Available from: $w w w . s c i e l o . b r / s c i e l o . p h p ? s c r i p t=s c i$ arttext\&pid=S1414-32832013000100017\&lng=en

2. Terra FS, Marziale MHP, Robazzi MLCC. Evaluation of Self-esteem in Nursing Teachers at Public and Private Universities. Rev Latino-Am Enfermagem [internet]. 2013 [cited 2014 Oct 23]; 21 (spe):211-8. Available from: http:/ / www.scielo.br/scielo/scielo.php?script=sci arttext\&pid=S0104-11692013000700010\&lng=en

3. Bettancourt L, Muñoz LA, Merighi MAB, Santos MF. Nursing teachers in clinical training areas: a phenomenological focus. Rev Latino-Am Enfermagem [internet]. 2011 [cited 2014 Oct 23]; 19(5):1197-204. Available from: http://www. scielo.br/scielo.php?script=sci_arttext\&pid $=$ S010411692011000500018\&lng=en 
4. Backes VMS, Moyá JLM, Prado ML. The construction process of pedagogical knowledge among nursing professors. Rev Latino-Am Enfermagem [internet]. 2011 [cited 2014 Oct 23]; 19(2):421-8. Available from: http:/ / www.scielo.br/scielo.php?script=sci arttext\&pid=S0104-11692011000200026\&lng=en

5. Lima TC, Paixão FRC, Cândido EC, Campos CJG, Ceolim MF. Estágio curricular supervisionado: análise da experiência discente. Rev Bras Enferm [internet]. 2014 [cited 2014 Oct 23]; 67(1):133-40. Available from: http:// www.scielo.br/scielo.php?script=sci arttext\&pid=S0034-71672014000100133\&lng=en

6. Bardin L. Análise de conteúdo. São Paulo (SP): Edições 70; 2011.

7. Minayo MCS, $\mathrm{O}$ desafio do conhecimento. $12^{\mathrm{a}}$ ed. São Paulo (SP): Hucitec; 2012.

8. Gil AC. Como elaborar projetos de pesquisa. 5 ed. São Paulo (SP): Atlas; 2010.

9. Silva LAS, Arboit EL, Müller LA, Prestes M, Dalmolin IS, Sassi, MM. Percepções de professores enfermeiros sobre a intersecção do trabalho assistencial e docente. Rev Enferm UFSM [internet]. 2014 [cited 2014 Oct 23]; 4(2):313-22. Available from: http://cascavel.ufsm. $\mathrm{br} /$ revistas/ojs-2.2.2/index.php/reufsm/article/ view/10081/pdf

10. Backes VMS, Moya JLM, Prado ML, Menegaz JC, Cunha AP, Francisco BS. Expressions of pedagogical content knowledge of an experienced nursing teacher. Texto Contexto Enferm [internet]. 2013 [cited 2014 Oct 23]; 22(3):. Available from: http://www. scielo.br/scielo.php?script=sci_arttext\&pid=S010407072013000300029\&lng=en

11. Morin E. Ométodo3: o conhecimento do conhecimento. $4^{\mathrm{a}}$ ed. Porto Alegre (RS): Sulina; 2012.

12. Cruz GV, Pereira WR. Diferentes configurações da violência nas relações pedagógicas entre docentes e discentes do ensino superior. Rev Bras Enferm [internet]. 2013 [cited 24 Nov 2014]; 66(2):241-50. Available from: http://www.scielo. $\mathrm{br} /$ scielo.php? script $=$ sci_arttext\&pid $=$ S003471672013000200014\&lng=en

13. Moura ECC, Mesquita LFC. Estratégias de ensinoaprendizagem na percepção de graduandos de enfermagem. Rev Bras Enferm. 2010 [cited 14 Nov 2014]; 63(5):739-98. Available from: http://www. scielo.br/scielo.php?script=sci_arttext\&pid=S003471672010000500016\&lng=en
14. Pereira WR, Ribeiro MRR, Depes VBSi, Santos NC. Emotional competencies in the process of teaching and learning in nursing, from the perspective of the neurosciences. Rev Latino-am Enfermagem [internet]. 2013 [cited 14 Nov 2014]; 21(3):663-9. Available from: http:/ / www.scielo.br/scielo.php? script $=$ sci_ arttext\&pid=S0104-11692013000300663\&lng=en

15. Faria JIL, Casagrande LDR. A educação para o século XXI e a formação do professor reflexivo na enfermagem. Rev Latino-Am Enfermagem [Internet]. 2004 Out [cited 2016 Apr 19]; 12(5):821-7. Available from: http:/ / www.scielo.br/scielo.php?script=sci_ arttext\&pid=S0104-11692004000500017\&lng=pt.

16. Silva Maia NMF, Vilar Teixeira BMN, Batista Moura Maria E. A participação discente no desenvolvimento do projeto pedagógico do curso de Enfermagem. Investigación Educ Enfermería [internet]. 2013 [cited 27 Jul 2015]; 31(2):190-8. Available from:http:/ / www.scielo.org.co/scielo.php? script $=$ sci $_{-}$ arttext\&pid=S0120-53072013000200003\&lng=es\&tl $\mathrm{ng}=\mathrm{pt}$

17. García ALC, Forero PC, Ocampo RD, Madrigal $\mathrm{RMC}$. The meaning of teaching and learning for professors. Investigación Educ Enfermería [internet]. 2015 [cited 27 Jul 2015]; 33(1):8-16. Available from: http:/ / www.scielo.org.co/scielo.php? script $=$ sci arttext\&pid=S0120-53072015000100002\&lng=es\&nr $\mathrm{m}=$ iso

18. Ramos FRS, Brehmer LCF, Vargas MAO, Schneider DG, Drago LC. Ethics constructed through the process of nurse training: conceptions, spaces and strategies. Rev Latino-Am Enfermagem [internet]. 2013 [cited 14 Nov 2014]; 21(spe):113-21. Available from http://www.scielo.br/scielo.php?script=sci_ arttext\&pid=S0104-11692013000700015\&lng=en

19. Germano RM. A pesquisa e os dilemas éticos do trabalho da Enfermagem. Rev Bras Enferm [internet]. 2013 [cited 14 Nov 2014]; 66(spe):76-9. Available from: http:/ / www.scielo.br/scielo.php? script $=$ sci $_{-}$ arttext\&pid=S0034-71672013000700010\&lng=en

20. Burgatti JC, Bracialli LAD, Oliveira MAC. Problemas éticos vivenciados no estagio curricular supervisionado em Enfermagem de um currículo integrado. Rev Esc Enferm. [internet]. 2013 [cited 14 Nov 2014]; 47(4):937-42 Available from: http:/ / www. scielo.br /scielo.php?script=sci_arttext\&pid $=$ S008062342013000400937\&lng=en 